\title{
Moving in a hierarchized landscape Changing border regimes in Central Kalimantan
}

\author{
DAVE LUMENTA
}

\begin{abstract}
Transnational mobility is a common feature among borderland communities. Central Borneo has been a relatively fluid and open riverine-based sociocultural and economic space since the arrival of colonial states, without much interference from the establishment of international boundaries on local crossborder mobility practices. This applies to the Kenyah, a cluster of related ethnic groups occupying the Apokayan plateau in East Kalimantan (Indonesia), who are historically an integral part of the socio-cultural and economic fabric throughout the major riverine systems of Sarawak (Malaysia). Despite the relative absence of states, Central Borneo has not escaped the onslaught of social differentiation embedded in nation-state identities. The penetration of Sarawak's logging industry has brought the terrestrial re-ordering of the Bornean landscape away from the relative egalitarian social order of river basins into hierarchical social relations embedded in capitalistic modes of production. This has brought about the construction of the Kenyah's visibility as an "Indonesian underclass" inside Sarawak.

KEYWORDS

Borneo, Kalimantan, mobility, borderlands, space, and capitalism.
\end{abstract}

\section{INTRODUCTION}

Strategically situated on the major maritime trade routes linking ancient Europe, India, and China, Southeast Asia has a long dynamic history marked by shifting powers and the intense movements of people, commodities, and cultural flows. The region's fluidity and openness is amply demonstrated by an abundance of shared cross-cultural influences within the region, such as technology, religious syncretism, language, diasporas, and even the consumption and preparation of food.

\footnotetext{
DAVE LUMENTA (1971) graduated from the Department of Anthropology of the University of Indonesia and obtained his doctorate at the Graduate School of Asian and African Studies at Kyoto University. He currently lectures at the Department of Anthropology of the University of Indonesia. His research interests cover state formation and social histories of borderlands in Southeast Asia. Dave Lumenta may be contacted at: dave.lumenta@ui.ac.id.
}

(C) 2011 Faculty of Humanities, University of Indonesia 
The arrival of colonialism and the subsequent emergence of post-colonial nation-states in the region have significantly re-configured and re-ordered patterns of human social life. Border regimes have become prominent actors in the regulation of the movement of peoples and commodities across borders, such as the establishment of customs and immigration control posts, and designated international routes and ports of entry. Coinciding with regional economic booms, the importance of border regimes has only increased among the ASEAN states in the mid-1980s in the wake of increased transnational labour migrations. However, departing from Bauman (1998), the recent structure of globalization also comes with new class dimensions and hierarchies that segregate the flow of peoples around the world, made possible by sophisticated regimes and the technology of border controls.

Nevertheless, numerous upland regions across mainland Southeast Asia, peripheral maritime regions such as the Sulu Sea, the Celebes Sea, and the internationally-partitioned island of Borneo, remain quasi-open and fluid spaces where peoples and commodities traverse international boundaries relatively unchecked by border controls. This indicates that states rarely reach a state of idealized omnipotence enabling them to wield total and coherent power over space and societal mobility. This is especially true for post-colonial states, not only in the ASEAN region, but also around the world. State borders throughout Southeast Asia have generally been established in an arbitrary fashion, where ethnic, linguistic, social, and economic borders never neatly coincided with formal state boundaries drawn on maps. Consequently, shared ethnicity, language, identity, and economic interconnectivity continue to transcend state boundaries. As such, in many upland borderland regions around Southeast Asia the nation-state remains an alien and contested notion (see Scott 2009; Van Schendel 2005).

This does not imply that national identities have made no inroads in these seemingly "stateless" and "unruly" backyards. Since the 1980s, even a remote but culturally fluid region like Central Borneo has not escaped the diverging onslaught of national identity inscriptions between 'Indonesians' and 'Malaysians'. The focus of this article is that this has been achieved not through the increased sophistication of state border controls, but rather by hierarchies created by the capitalist transformation of the Central Bornean landscape.

The history of Kenyah mobility from the Apokayan highlands (in today's Indonesia) into Sarawak (today's Malaysia) provides a dramatic, if not tragic, example of how an ethnic group gradually became alienated from Sarawak's social and economic fabric of which they were an integrated and significant part. Instead of attributing this 'success' to effective border control, the power of national schooling, or even to the outcome of international conflicts like the Konfrontasi which was actually experienced as a full-scaled war in Central Borneo, my final examination looks at the capitalist-based structural ordering of the Sarawak space itself, which has been an effective substitution for any organizational state power in bringing about a visible social demarcation between "Indonesians" and "Malaysians" in Central Borneo. 
One major theme in the discussion of border regimes revolves around two dialectical historical trajectories - partitionary nation-state building that calls for spatial partition and the sedentarization of peoples on one hand and capitalist-driven globalization calling for open borders to facilitate unhindered circulation of capital and labour on the other. ${ }^{1}$

Nation-state spaces operate on the principle of fixity and bounded homogeneity. Indeed, states are inherently obsessed with tying people to specific places and to assign them coherent identities, in other words, to turn them into "geobodies" (for example, Scott 1998; Migdal 2004; Thongchai Winichakul 1994). States are inherently constructed to function as spatial barriers, but capitalism continuously strives to do away with spatial barriers (Marx 1973). Congruent to the latter, even traditional mobility practices and spatial orientation of the most remote communities throughout the world was often tied to efforts in seeking shorter and more favourable trade routes to the nearest markets. The persistent mobility practices in borderland regions in defiance of today's state boundaries are often rooted in ancient trade routes that may have been the most efficient links between supply regions to regional markets. These very same routes may be as efficient today as they were in the past, and serving the same purposes under contemporary capitalist modes of development as they had been under maritime-trade regimes of the ancient past. During the early stages of mercantilist capitalism in Southeast Asia, colonial powers suppressed traditional mobility practices such as trading expeditions precisely because they were all too compatible with and responsive to the demands of the capitalist system itself - bypassing trade monopolies, colonial tax barriers, and inefficient trading routes. ${ }^{2} \mathrm{Up}$ to this point, because each has their own logic of space, it appears that capitalism and people who freely move around are not conveniently compatible with state projects.

Marxist geography (for example, Lefebvre 1991; Smith 1990) particularly focuses on the mechanisms through which space is appropriated - how it is constructed, visualized, designated, seized, and projected back - to serve capital (or class) interests. In order to overcome natural barriers in order to accelerate the extraction of resources, the re-organization of space is a pre-requisite. The invention of new modes of production, technology, and collaboration with states enables the speedy re-configuration of landscapes to accelerate the efficient movement of resources from their natural deposits to markets. Terrestrial developmentalism has been a major undertaking throughout the world. The invention of roads, logging roads, ports, dams, towns, the sedentarization of human settlements, and transmigration schemes are all manifestations of the capital drive to subjugate the landscape. These

1 Ishikawa (2008), for example, referred to these two forces as "the organizational power of the state" and "the structural power of capitalism".

For example, the diaspora of Bugis merchants towards the Malacca Strait was at a certain stage the direct result of Dutch efforts to surpress direct trading links between Makassar and British merchants, which undermined Dutch trading interests in the region (see Poelinggomang 2002). 
inventions are expected to create embedded social structures that are expected to conform to the maximization of capital accumulation. This includes, for example, the importation of labour, the creation of middle class suburbs, and even the forced displacements of peoples. The latter section of the examination of the history of Kenyah mobility deals especially with the effects of the logging industry and how it has altered and impacted not only on the landscape, but also on new modes of social relations.

Riverine SPACES: Central Kalimantan's PAST SOCIAL, ECONOMIC, AND POLITICAL ORGANIZATION

Trans-basin trade and interethnic social interactions and migrations have been constant features of social organization among Central Borneo's communities (Rousseau 1990; Sellato 2001; Eghenter 1999). Rousseau (1990: 301-302) suggests that Central Borneo societies can be better analysed when seen as river basin societies rather than as closed village units. Rousseau's model can be applied to transnational trans-basin societies to analyse Central Borneo groups that have extensive trans-basin relations under the current international partition (Figure 1).

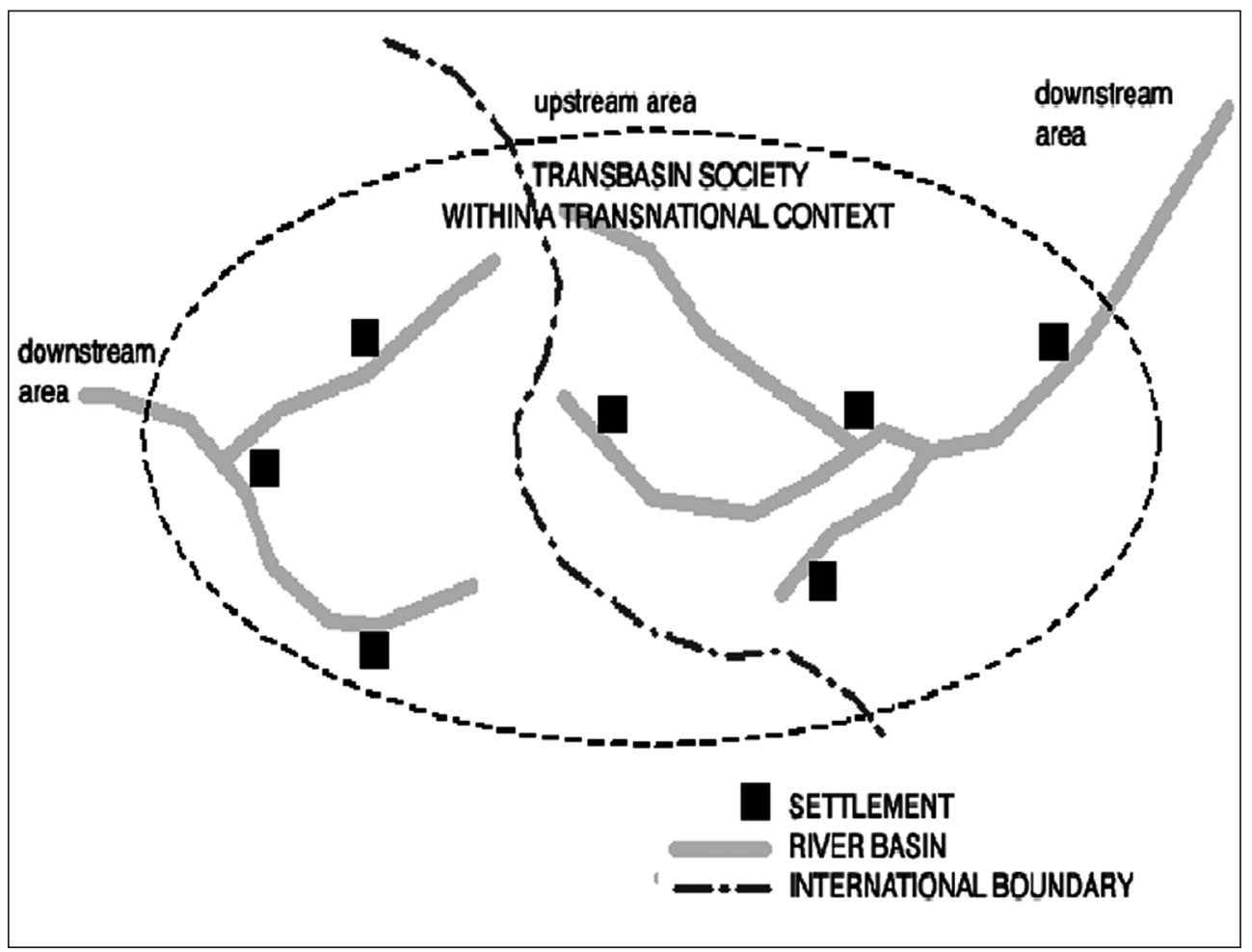

Figure 1. Trans-basin society (Rousseau 1990).

In general, State borders throughout Southeast Asia have been established in an arbitrary fashion, where formal state boundaries drawn on maps never 
neatly intersected with ethnic, linguistic, social, and economic borders. As a result, shared ethnicity, language, identity, and economic interconnectivity continue to transcend many state boundaries.

The island of Borneo (Map 1) is not only a fitting example of these arbitrary state partitioning processes (being partitioned into three different nationstates), but it serves as an ideal site of inquiry to examine the seemingly absence of state border regimes and the far penetrating effects of the capitalist reordering of the landscape.

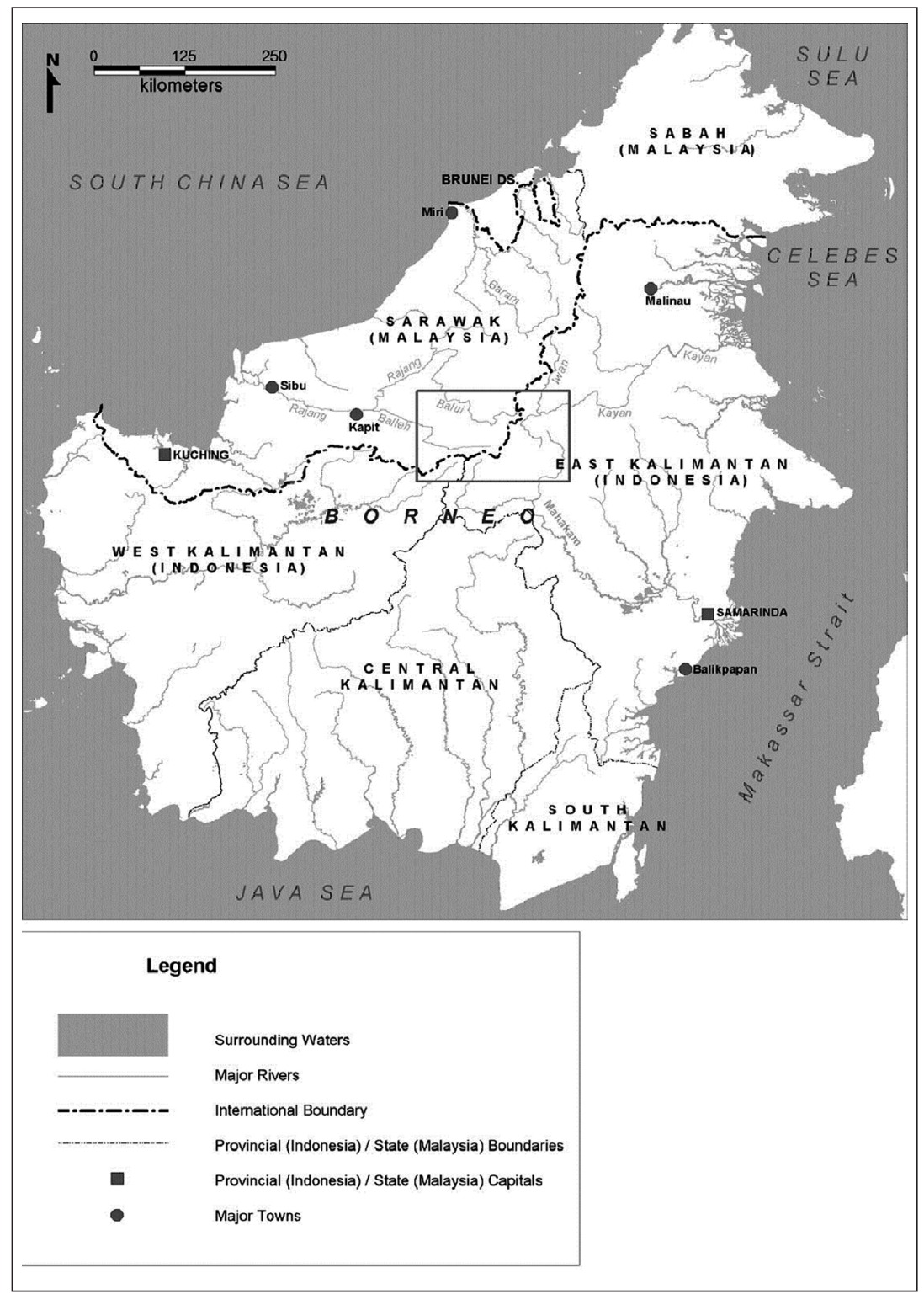

Map 1. Research site: Central Borneo. 
The colonial partitioning of Borneo by the 1891 Anglo-Dutch Boundary Agreement was primarily based on the division of the river basins. ${ }^{3}$ It soon became evident that the mere division and control over river basins did not effectively bring about the smooth integration of the societies living in these basins into the sphere of (nation) states consistent with the partition agreement. The international boundary did little to curb Apokayan Kenyah mobility into Sarawak. In fact, continuing trade with Sarawak was a major income for the Kenyah enabling them to pay Dutch door-taxes. The dismal possibilities for integrating the Apokayan's economy into the Dutch and subsequent Indonesian space have so far rendered the region an economic liability, and each successive Dutch and Indonesian governments tacitly acknowledged that the Apokayan's economic survival rests largely on profits and revenues generated from neighbouring Sarawak. ${ }^{4}$

This inquiry focuses on a continuous geographical and social space that I will loosely define as Central Borneo, which encompasses parts of the Malaysian State of Sarawak and the Indonesian province of East Kalimantan. This region constitutes a transnational socio-cultural continuum that is rooted in the continuing flows of peoples, commodities, and ideas between the river basins for at least three centuries.

Social and economic trans-basin relationships between present day Kalimantan and Sarawak, characterized by inter-basin westward oriented trade towards the South China Sea - hence, through Sarawak - was a feature that existed before the arrival of colonial states in Borneo. Forest and animal products such as gutta percha, India rubber, rhinoceros horns, bezoars stones and later eaglewood primarily catered for Chinese market demands throughout Southeast Asia. Social networks surrounded these chains of commodity flows, which in turn determined the mobility orientation of many interior peoples in Central Borneo towards the South China Sea (see Ooi Keat Gin 1997). This explains why many borderland communities in present-day West and East Kalimantan on the Indonesian side of the border maintain close social affinities with riverine communities in Sarawak. In addition, the absence of a hegemonic Sultanate on Sarawak's coastal estuaries may also have been an attraction for the trade to flow westward. This is in sharp contrast with Borneo's east coast where coastal Sultanates like Kutai, Bulungan, and Berau heavily taxed commodities entering from the interior. For example, as our case study will demonstrate, the Kenyah of the Apokayan were particularly reluctant, if not defiant, to Dutch efforts in the early twentieth century to reorient their trading activities eastwards, away from Sarawak (Elshout 1923).

Colonial Sarawak (1841-1946) under the regimes of three successive 'White Rajahs' (James Brooke, Charles Brooke, and Charles Vyner Brooke) sits as an anomaly among its colonial contemporaries. Compared to British and Dutch colonies elsewhere in the region, Sarawak was immensely poor

3 See "Convention between Great Britain and the Netherlands defining boundaries in Borneo - Signed at London, June 20, 1891" in Staatsblad van het Koninkrijk der Nederlanden.

4 Lumenta (2008: 112-132). 
in terms of mineral deposits (oil was only discovered in the 1920s) and soil fertility. Lacking significant export revenues, Sarawak's bureaucracy was small and underfunded. As a result, its style of governance was largely personal and informal, enabling Sarawak officials to have close rapport with their indigenous subjects. Viewing themselves as the protectors of the status quo of the "native" traditional ways of life, the Brookes resisted any attempt to bring Sarawak under the influence of land-hungry British plantation capitalists. They believed that loss of native lands to capital interests would bring turmoil to Sarawak. The sole solution to Sarawak's dire economic situation was to promote the free trade of jungle products - which the Brookes believed would bring a sensible and non-destructive pace of "civilization" to the native ethnic groups in Sarawak. ${ }^{5}$ This also led to Brooke policies, as subsequent sections below will illustrate, that were relatively liberal towards the influx of indigenous trade expeditions coming from across the border. The British colonial period inherited the liberal attitudes towards the Apokayan Kenyah from the Brooke period. The formation of Malaysia in 1963 and the resulting Indonesia-Malaysia Confrontation initiated an evolutionary process of disciplining the influx of Indonesians into Sarawak, reaching its apex in 1985 after Indonesia and Malaysia formalized procedures for border crossings and when Malaysia initiated nationwide raids targeting "illegals". The Apokayan Kenyah were relatively less affected due to the absence of state border controls in central Borneo, although the new attitudes of the Malaysian state significantly limited their mobility space to the interior. Simultaneously, Sarawak's logging industry penetrated the Central Borneo highlands since the late 1980s, bringing along the construction of roads and job opportunities for the Indonesian populace across the border in Kalimantan.

\section{THE HISTORY OF KENYAH MOBILITY FROM EAST KALIMANTAN TO SARAWAK (1900-2007)}

The Kenyah, an umbrella ethnic identity for several culturally, historically, and linguistically related swidden agricultural groups, constitutes the majority of the population in Central Borneo. The largest cluster of Kenyah settlements is found in the Apokayan highlands in today's East Kalimantan Province in Indonesia adjacent to the Sarawak border. Being strategically located at the headwaters of major river basins that flow from the Apokayan-Iran highlands in centrifugal directions to Borneo's west and east coasts, the Kenyah played a central role in bringing forest products (and later agricultural labour) from the interior to downstream commercial centers. This was undertaken through a traditional mobility practice, principally undertaken by men, called peselai (literally 'to go on a long journey' - or 'merantau' in Malay), previously rooted in both head hunting and trade expeditions. The social significance of peselai was to initiate the coming of age of men by elders, while the economic significance lay in the provision of much-sought lowland commodities that could not be 
procured locally, such as salt, beads, iron, and much later, outboard engines, medicines, chainsaws, and money. Peselai expeditions often functioned as political missions to negotiate the opening of new trading routes with neighbouring ethnic groups, and on a broader scale, helped to deepen the relationships between the Apokayan Kenyah with communities of different river systems, particularly in Sarawak. No less important was that this also led to the flow of cultural ideas from the Apokayan. ${ }^{6}$

The transformation of peselai expeditions and its changing contexts reflect the socio-economic inclusion of the Kenyah within Sarawak during the Brooke period up to their current state/corporate-driven socio-economic exclusion and alienation from Sarawak.

\section{PRELUDE: THE EARLY BROOKE YEARS}

Brooke pacification policies gradually produced successful outcomes along the Rajang river basin and were immediately followed by the establishment of bazaar centers that sprung up around forts like Kapit (1879) and Belaga (1884), where Malay and Chinese traders lost no time to seize opportunities to barter coastal commodities such as belacu (crude unbleached cotton), tobacco, beads, salt, and sugar with much-valued forest products extracted by upriver communities, such as geliga (bezoar stones), gutta percha, jelutong (wild rubber), India-rubber, and rhinoceros horns. ${ }^{7}$

In January 1884, the Brooke Resident of Sarawak's Third (Rajang) Division, Hugh Brooke-Low reported the presence of the Apokayan Kenyah in Sarawak, when a small band of Leppo' Tau and Leppo' Tepu Kenyah sub-groups from the Apokayan 'stirred trouble and took heads' in the Tubau area, by then an important trading hub for Brunei merchants near Belaga. Brooke-Low also reported that the Leppo' Timai Kenyah were at the time contemplating to migrate from the Apokayan to the Balleh River in order to evade the Balui Kayan hostilities they often faced on their routes to trading outposts along the Rajang River. ${ }^{8}$ He had earlier reported about these troubles on the Balui route when 31 persons were killed during raidings between Balui Kayans and the Kenyah from the Apokayan. ${ }^{9}$

Further evidence also shows that trading expeditions from the Apokayan to the Rajang and Baram river basins were often impeded by frequent Iban

$6 \quad$ More on Peselai see Elshout 1923; Whittier 1973; Jessup 1981; Lumenta 2008.

$7 \quad$ Charles Brooke initially established both Kapit (1879) and Belaga (1884) as military frontier posts to check and curb Iban migratory expansions and headhunting raids to the Upper Rajang and Upper Balleh rivers. See Maxwell (1999) on the establishment Belaga, and Pringle (1970: 255n-257n) for a history of Brooke's policies pertaining to Iban expansion in the Rajang and Balleh rivers. On the general role of Chinese pioneers in the Sarawak trade, see Chew (1990). See also Eghenter (2001) and Ooi Keat Gin (1997) on the history of traded items.

Sarawak Gazette 2 June 1884. It must be noted that the Apokayan was de facto not a territorial part of any colonial power before 1911. On Tubau, see N. Ishikawa and M. Ishikawa (2005). The Tubau area by then functioned as an important trading hub for Brunei merchants. Sarawak Gazette 2 August 1882. 
ambushes making both trading routes unsafe. ${ }^{10}$ Despite the widespread hostilities between the Apokayan and communities along Sarawak's rivers, Brooke residents noted that the Apokayan Kenyah (who at the time consisted among others of the Uma' Kulit, Lepo' Tau, Badeng sub-groups) were keen to trade with Sarawak bazaars, and that this might be the key to establishing peace in Sarawak's upriver regions. On a head taking incident in 1889 between the Uma' Kulit Kenyah from the Apokayan with upriver Sarawak Ibans, C.A. Bampfylde, Resident of the Third (Rajang) Division reported:

Upriver Affairs. - From Belaga fort I received news that Pingan Sorang had imposed a very heavy fine on the Uma Kulits of Batang Kayan, but whether this fine has been paid or not is unknown: several young up-river Dyaks having expressed their intention of going on the war path against these Uma Kulits were promptly stopped by the chiefs. (C.A. Bampfylde, Resident Third Division, 1 April 1889). ${ }^{11}$

This quoted report indicates that Brooke officials were aware that PeIngan Surang, the paramount chief of the Leppo' Tau Kenyah of the Apokayan, exerted political influence over other Apokayan groups.

In 1897, the Leppo' Tau Kenyah appealed for peace to the Baram Resident, Charles Hose, in order to establish friendly relations and to open trading opportunities with communities along the Baram. Hose personally went to broker the peace deal by involving the Badeng Kenyah, who were on good terms with both the Kayan and Kenyah communities along the Baram and the Leppo' Tau Kenyah of the Apokayan, to act as peace mediators. The following passage exemplifies the "Brooke approach" to the Apokayan problem:

Whilst in the Madang villages I met a party of Keniahs from the Batang Kayan river, who had been sent by Tama Kuling and Tama Poyang, the Leppu Tau and Uma Kulit Chiefs, to inform me, that they were anxious to visit the people of Baram, and to meet me at Claudetown, with the intention of making friends with the people of this district and those of the Batang Kayan. They are also anxious to find an outlet for their trade. I consulted with Tama Bulan and the other chiefs present, and we decided to send presents of gongs and white cloth to several of the Batang Kayan chiefs. (Charles Hose, Resident Fifth Division, 1899). ${ }^{12}$

On another occasion, one Uma' Kulit Kenyah envoy was reported visiting the Kapit Resident, upon which the latter reported,

Although at present they have no intention of moving from their present abodes in the Batang Kayan, these people are very anxious to establish friendly relations with ... especially the Dyaks of the Batang Rejang. I am therefore affording them every opportunity to meet the principal Dyak chiefs ... The Uma Kulits are disirous [sic] to be able to trade with and obtain their supplies from Sarawak territory in future

10 See Nieuwenhuis (1929: 32) who wrote, based on his 1900 visit, that "On their trading trips to the river Batang-Redjang and the river Barom [original] they had hitherto always been ambushed by Hiwans of these parts".

11 Sarawak Gazette 1 August 1899.

12 Sarawak Gazette 3 January 1899. 
and say they will gladly welcome Dyak forest products seekers. (H.F. Deshon, Kapit Resident, 1898). ${ }^{13}$

Charles Brooke's personal invitation in 1899 to meet and persuade PeIngan Surang to move the Apokayan Kenyah over to Sarawak should be seen in the context of the ongoing hostilities between upriver communities. PeIngan Surang reached Kapit and Sibu in March 1900 with a group of 500 Kenyah who reportedly traded high quality gutta percha and India rubber in exchange for salt and other goods, valued at "thousands of dollars". ${ }^{14}$ Another party led by Bui Jalong went down the Baram River to Claudetown (Marudi) near Brunei. Charles Brooke took the opportunity to invite both parties to a conference in Kuching, where PeIngan Sorang stated that they found the Rajang markets "more accessible and preferable" as long as peace with the Iban Dayaks, who were considered Brooke subjects, was maintained..$^{15}$ The party returned to the Apokayan, soon finding themselves raided again by Ibans in the Upper Balleh. ${ }^{16}$

The establishment of the Kapit and Belaga bazaars provided the Apokayan Kenyah with alternative and shorter trade routes compared to the routes they used to take to the east, which were fraught with geographical obstacles, hostile relations with Mahakam Bahaus, and the Kutai Sultanate's trade monopoly over the Mahakam River. ${ }^{17}$ Moreover, access from the Apokayan to the lower Kayan near Tanjungselor (Bulungan) was, until the Dutch managed to broker peace in 1907, hampered by a hostile Uma Alim Kenyah settlement just above the Brem Brem rapids. ${ }^{18}$

\section{THE 1924 KAPIT PEACEMAKING AGREEMENT AND THE LIBERALIZATION} OF HUMAN TRAFFIC

What really irritated both the Brooke and the Dutch Government were the ongoing, though sporadic, hostilities between Ibans of the Balleh and the Apokayan Kenyah, which reached a peak in 1921. Brooke officials took the effort to take the 350-mile roundtrip journey to Long Nawang to negotiate a peace settlement that would involve the Apokayan Kenyah, the Dutch controleur of the Apokayan and the Balleh Ibans. Brooke officers both knew that they would not arrive at a peacemaking settlement if the customs of only one warring party were observed and not those of the others. They travelled with a party of Balleh Ibans to Long Nawang to make preparations for a preliminary peacemaking agreement following Kenyah customs, overseen by both Brooke's officials and the Dutch controleur Molenaar. ${ }^{19}$ The Long Nawang

13 Sarawak Gazette 1 July 1898.

14 See Beccari (1904: 362). Beccari, an Italian naturalist, by mistake identified this Kenyah group for 'Kayans'.

15 Sarawak Gazette 1 March 1901.

16 See Whittier (1973: 33-34) and Smythies (1955: 506-507).

17 See Whittier (1973) and Elshout (1923).

18 See Van Walchren (1907).

19 Eghenter (2001) noted that local Dutch controleurs of the Apokayan also favoured 
peacemaking ceremony was concluded in May 1924, and both the Apokayan Kenyah and the Balleh Ibans agreed to a date when the next peacemaking ceremony would be undertaken following Iban customs. ${ }^{20}$

The Kapit peacemaking ceremony on 26 November 1924 was attended by Rajah Charles Vyner Brooke, the respective Brooke and Dutch officials and approximately 4,200 "natives", including the Apokayan Kenyah delegation consisting of 960 men who arrived in 97 canoes from the Apokayan. Charles Vyner Brooke himself came up to Kapit to oversee the proceedings and presented tokens of peace in the form of ancient jars to the Iban Penghulu Koh and the Kenyah paramount chief leader, Taman Kila. Apart from bringing permanent peace to Central Borneo, this move was also made for economic reasons. The agreement was hoped, in the words of G.T.M. MacBryan who organized the event, to

[...] encourage freer intercourse between Sarawak and Dutch Borneo to the benefit of the inhabitants of these rivers, in that they will be able to proceed unmolested about their business, and open up the vast country of the Rajang head waters for the working of forest products and to peaceful trade (G.T.M. MacBryan, Sarawak Gazette 1 October 1924).

Charles Vyner Brooke personally invited controleur Molenaar and the leading Apokayan chiefs to join him on his journey back to Kuching. The high appreciation the Brooke Government placed on the Kapit peacemaking agreement is expressed by the following letter the Sarawak Chief Secretary sent to the Dutch Government in Batavia:

Afterwards, on the invitation of His Highness the Rajah, Captain Molenaar brought some of the more important chiefs and their followers on to Kuching, the capital of Sarawak, where entertainment was provided for them. His Highness yacht was lent to them for the journey to and from Kuching ... His Highness wishes to express his keen appreciation of the excellent behaviour of the Kayans and Kenyahs under Captain Molenaar ... the Sarawak natives reciprocated in a remarkable way and it is thought that the Peace-making in itself will remain for a very long time in the memory of all who attended it, and that as a factor in the future prosperity on the Dutch - Sarawak Border it will have a far-reaching and beneficial effect. ${ }^{21}$

The Kapit peacemaking ceremony paved the way for the Apokayan Kenyah to gain unhindered access to Sarawak markets. In return, the Balleh Ibans were granted access to collect jungle products in Dutch Borneo. Through this liberalization of human traffic, the Apokayan Kenyah were able to increase their economic and social role in the Balui, Balleh and Rajang rivers.

The opening of oil fields near Miri and Kuala Baram, discovered in

trade with Sarawak as opposed to central government efforts to divert trading activities into its own controlled territories.

$20 \quad$ Sarawak Gazette 1 October 1924.

21 Politiek Verslag 24 December 1924, "Letter from the Chief Secretary of Sarawak on the Kapit peacemaking", Nationaal Archief, Den Haag. 
the 1920s, required the mass recruitment of labour to clear coastal swamp forests. ${ }^{22}$ Kenyah peselai expeditions to the lower Baram were able to combine trading activities with wage-labour jobs..$^{23}$ The following story typifies peselai expeditions in this period, as told by Lencau Bilong, who accordingly went on his first peselai just before the Second World War:

It was a difficult journey as there were no motorized boats at that time. We had to paddle up and haul our canoes through the rapids along the Iwan River for two weeks, leave our canoes at Long Adan and cross the Iran Mountains until we reached the Upper Danum River. We spent five days building new canoes. It took us another, maybe two weeks, until we reached the Upper Tiyut River. As we were running out of food stocks, we were desperate to find a nearby longhouse where we could find rice. However, a band of hostile Punans met us across the mountain at the headwaters of the Weng River. They had their blowpipes aimed at us. Only after we explained that we were Ngulo Arang's grandchildren did they let us pass. (Lencau Bilong). ${ }^{24}$

\section{THE BRITISH COLONIAL PERIOD: TRADE, CULTURE, LABOUR}

During the immediate post-war years, expeditions resumed and expanded to the growing sawmill and logging industries along Sarawak's coastal towns such as Binatang (Bintangor), Sibu, Sarikei, and the emerging town of Bintulu. The coastal areas were still an unknown world for many Kenyah, as the Bintulu District Officer reported in 1948:

On the $15^{\text {th }}$ July, Penghulu Ovat Mereng came down from Tubau with thirty-two Kenyahs from Long Newang [original] Most of the Kenyahs had never seen the sea before. (Mr. Jacks, Bintulu District Officer, 1948). ${ }^{25}$

The influx of peselai expeditions into Sarawak during this period were accompanied by flows of cultural ideas. The Apokayan in the late 1940s became the springboard for two new religions that successfully spread and won converts in Sarawak.

Not long after the dawn of the Bungan cult, a reformist movement of the old Kenyah Adet Pu'un religion, peselai expedition members brought over the new Bungan cult to the neighboring Balui and Baram river systems in Sarawak. Around 1954, Bungan followers within peselai teams successfully attracted and converted Kayan and Kenyah communities along the Balui River, including influential Kayan longhouses near Belaga. The Bungan cult also spread rapidly during the 1950s in the Baram River and seriously undermined the missionary work of Catholic and BEM (Borneo Evangelical Mission) missions. Simultaneously, Christianity also spread into Sarawak's Balui and Baram river systems through other peselai teams and both Apokayan and Bahau Kenyah migrants who had settled in Sarawak. Christian influence in the Balui started

22 See also Amarjit Kaur (1998b: 127-128).

23 Interview with Lencau Bilong, Nawang Baru, May 2001 and February 2003.

24 Interview with Lencau Bilong, Nawang Baru, February 2003. Ngulo Arang was the chief of the Leppo' Tau Kenyah in the Baram.

25 Sarawak Gazette 1 December 1948. 
with the migration of the Uma' Kulit Kenyah from the Apokayan to Long Jawe. When BEM's Rev. Ray Cunningham made his pioneering mission expedition to the Balui in 1952, he unexpectedly discovered that the most upriver Kenyah settlement had large numbers of Christians who had converted since their days in Indonesia. He recruited a number of Long Jawe Christians to assist mission work downstream. ${ }^{26}$ With the entrance of the Bungan cult and Christianity in Sarawak in the period 1952-1963, the Adet Pu' un rapidly lost its followers among Kayan and Kenyah villages throughout Sarawak. By 1962, all the villages in the Baram were either Bungan or Roman Catholic and almost the entire Balui valley was listed as "Bungan" with the exception of two Christian Kenyah villages (Prattis 1963). It was also around this time that parts of the New Testament were translated in the Long Nawang Kenyah Leppo' Tau dialect by peselai teams working at swamp timber sites in Suai. Pastor Balan Engan gives some more explanation of the origins of the Kenyah version of the New Testament (Tukat Madieng):

The Tukat Madieng was translated using the Indonesian Kenyah Leppo' Tau dialect because the late Reverend Ray Cunningham, who proselytized among the Kenyah during the 1950s, had problems in finding local Sarawakian Kenyah who were willing to do the translations. They were maybe just too lazy and disinterested. He found willing Indonesian Kenyah workers at a timber camp near Miri - it was a camp in Suai. They all originated from Long Nawang, and they were all Leppo' Tau. Cunningham lived in with these workers until the important passages of the Testament were translated. This happened around 1956. Of course, some church council members objected, saying that it should've been translated by morally qualified church members instead of filthy booze-drinking logging workers! But anyways, these workers had sufficient biblical knowledgeable that they knew how to translate it properly. These earlier translations were widely used before a new translation came out in 1978 - but it was mainly based on the earlier translations - so they kept the (Indonesian) Leppo' Tau Kenyah dialect, which is widely understood anyways in Sarawak. (Pastor Balan Engan). ${ }^{27}$

Peselai group members would often spend their wages on various items that would be hauled all the way back to the Apokayan. Below is a typical scene of a returning peselai group, as described by the Kapit District Officer in 1957:

Six parties of USI [United States of Indonesia] Kenyahs comprising 91 men returned to Indonesian Borneo by the Tassoh-Majang path. They bought stoves with the money they made by working with some timber firms in Sibu. All appeared to have wristwatches and sewing machines and other stores totalled [sic] eight shoulder loads each to carry over a seven mile distance. All these people caused no trouble. (Hermanus Assan, Kapit District Officer, 1957). ${ }^{28}$

As the rubber and illipe nut (engkabang or tengkawang) trade boomed in Sarawak, more Kenyah groups entered the Rajang River during harvest

26 Sidang Injil Borneo (1988: 26).

27 Interview with Pastor Balan Engan (SIB), Miri, October 2005.

281957 Kapit District report by District Officer Hermanus Assan (Sarawak Gazette 31 March 1958). 
seasons as sharecroppers. ${ }^{29}$ Labour shortage in Sarawak's Third Division (Rajang) became acute as Iban villages along the Rajang were unable to handle the simultaneous rice, para-rubber and illipe nut harvests in 19571959 due to the absence of sufficient male Iban labour. ${ }^{30}$ This situation was further exacerbated when the Sarawak government requested additional labour to construct the Belaga airstrip in 1958. This problem was solved when approximately 500 Kenyah from the Apokayan arrived in Belaga to meet the labour shortage, while an additional 100 Kenyah arrived at Nanga Merirai by invitation of Temenggong Jugah to assist in weeding and harvesting.

Evidence indicates that the implementation of the Pass Djalan policy was left to the discretion of resident officials, who apparently considered the legal issue of border crossing of secondary importance. For example, during the 1958 mass recruitment of workers in Belaga, not all Kenyah possessed a valid Pass Djalan. Most of the Kenyah from Long Nawang recruited for the Belaga airstrip construction only had a Surat Keterangan (Recommendation Letter) signed by tua kampongs (village chiefs) instead of by the Wedana, rendering their entry illegal. ${ }^{31}$ District Residents, however, had more positive, if not liberal, views on the Kenyah influx, as the following passages written by District Officers in charge ex-officio over immigration affairs, illustrate

Labour was seriously in want. The shortage would have been worse were it not for the hundreds of Kenyahs from the U.S.I. [original] who plugged the gaps. (Hermanus Assan, Kapit District Officer, 1958). ${ }^{32}$

Parties of Kenyahs have continued to arrive in the Baram. Good workers and excellent citizens they have caused no trouble of any kind. A few of the younger men marry and apply for permission to remain in Sarawak but otherwise there have been no requests to settle. (M.M. McSporran, Baram District Officer, 1959). ${ }^{33}$

Even officials who had reservations about the peselai influx were evidently more concerned with local impacts rather than questioning the legality of such influxes:

The arrival of large numbers of Indonesian Kenyahs in Belaga en route to Kapit and the Lower Rejang presented a problem to longhouses on the Balui, who feel traditionally obligated to feed and house them. A party of forty migrant labourers held up in a longhouse for three or four days by high water is a burden on any small community. (W.C.B. Wilson, Kapit District Officer, 1959). ${ }^{34}$

29 Illipe nut harvests peaked throughout Sarawak in 1954 and 1958, coinciding with soaring Illipe nut prices since 1953. See B.E. Smythies' report on the uses of illipe nuts in Sarawak Gazette (31 August 1958: 146-148).

30 Many Ibans in the Kapit Division were recruited into the Sarawak Rangers fighting Communism in Malaya, in addition to those who headed towards Seria in Brunei to work on the oil refineries. As the Kapit resident reported in 1957, Iban male labour absence in his division reached levels of up to $40 \%$ of the total Iban male population. (Sarawak Gazette 31 March 1958).

31 See Sarawak Gazette 31 May 1959: 113. On the invalidity of a Surat Keterangan, see Sarawak Gazette 30 November 1958: 222.

321958 Kapit District Report (Sarawak Gazette 31 May 1959: 114).

331959 Baram District Report (Sarawak Gazette 31 October 1959: 247).

341959 Kapit District Report (Sarawak Gazette 31 May 1960: 119). 
In fact, in District Officer reports the influx of Kenyah workers remained reported until 1964 under "Native Issues" rather than in the "Immigration" sections. Peselai teams working at the Belaga airfield in 1958 brought significant influences of Christianity and Kenyah art forms to nearby Badeng Kenyah villages, such as Long Geng. ${ }^{35}$ Upon hearing of their presence at the Belaga airfield project, Tom Harrisson, the Curator of the Sarawak Museum (19461966) in Kuching, invited several of his old Kenyah friends that he knew from his days in Long Nawang to Kuching and commissioned them to make artwork for the Sarawak Museum. As Harrisson (1966: page) wrote:

The Leppo Tau Kenyahs of Long Nawang, upper (Apo) Batang Kayan, Kalimantan, are regarded by all other Kenyahs as the top "class", the repository of the "purest" form of their culture and the centre of their oldest and most important cultural aristocracy. The symbol of this situation when I visited Long Nawang in 1945 as the great "Tree of Life" painted on the wall of the magnificent house used for communal meetings and rites. That house has since decayed and never been rebuilt, but I succeeded in getting the original artists to come to Kuching later and reproduced the same superb design for living inside the Sarawak Museum -though there is not room here to do it at a full-scale.

It took nearly two years to finish the commission and the murals were only completed in 1960. PeBit Ncuk along with Tusau Padan were commissioned to make traditional Kenyah carvings for display in the museum and to contribute articles about Leppo' Tau Kenyah traditions in the Sarawak Museum Journal. ${ }^{36}$ Tusau Padan became a renowned Kenyah artist throughout Sarawak, and he opted to settle there permanently. ${ }^{37}$ Harrisson also recruited other young peselai members to help with the excavation of the Museum's Batu Niah Cave project. This particular period illustrates the centrality of the Apokayan to important religious transformations occurring in upriver Sarawak, as well as the inclusionary attitudes of the Sarawak state towards the Apokayan Kenyah. It similarly marked the last phase of peselai expeditions into Sarawak when they were not yet seen as "illegal" or as "Indonesians".

\section{THE LONG JAWE INCIDENT AND KONFRONTASI (1963-1966)}

Political and security tensions began to build-up throughout Sarawak following the 1962 Brunei Rebellion; the earliest indications of Indonesian political and armed support to the rebels soon alerted British officials to intensify control over all cross-border movements between Sarawak and Kalimantan. Gurkha patrols were stationed off the entire Sarawak coastline up to the upper reaches of the interior rivers to check on the movements of Indonesians. Despite mass deportations of Indonesians from other parts of Sarawak, the Apokayan Kenyah were evidently granted different treatment. ${ }^{38}$

35 Personal communication with Jayl Langub, Kuching, March 2005.

36 See Pabit Enjok 1965.

37 Being a skilled musician and dancer, he became a regular Sarawak cultural envoy on Malaysian cultural missions overseas during the 1970s and 1980s (Langub 1997).

38 On deportations of Indonesian labour, see Sarawak Gazette (January 1964). 
We were longing for home, but we heard that Sarawak's entire coastline was swarming with military checkpoints, all the way up to Kapit. We asked Tuan Rison (Tom Harrisson) for a clearance order that would waive us from all the checkpoints up to Long Nawang. ${ }^{39}$ We were the only (peselai) group who had managed to return safely to Long Nawang during the time of Konfrontasi, thanks to Tuan Rison. I think he wanted to pay back all the favours my elders had done for him during the war years. My elders were the ones who helped him, but it was through me that he repaid his gratitude. (Ubang Ding)..$^{40}$

The last peselai teams who managed to pass through Gurkha checkpoints were barely one month back home when they were sent back into Sarawak for a total different purpose.

A group of approximately 200 Kenyah men from Long Nawang under the leadership of two Indonesian marine majors and additional auxiliary TNKU militias went to attack the Gurkha military outstation at the Uma' Kulit village of Long Jawe in late September $1963 .{ }^{41}$ Many Kenyah men were told that their mission was to 'liberate Brunei from the English colonizers', though the destination was not disclosed until the parties were several kilometers upriver from Long Jawe. The Indonesian military leaders assured the Kenyah that the attack would not be directed against the Long Jawe population, whom the officers knew had still close kinship relations with the Apokayan Kenyah. Kenyah scouts of the raiding party were sent ahead and even managed to slip into the longhouses to warn about the impending attack so that no Kenyah would be in shooting range, which was to be directed towards the Gurkha outpost across the river. The attack was launched on 28 September 1963, and to the dismay of the attacking Kenyah, the Gurkhas also employed local Long Jawe Kenyah as border scouts, some of whom were killed that day. The raiding party intended to kidnap four of these scouts to prevent them from sounding the alarm. The military leaders, however, had decided that the captives should be executed on the spot against the wishes of the Kenyah team members. Two were silently helped by the Kenyah to escape. The deaths of the four Uma' Kulit Kenyah border scouts, however, has already antagonized the Long Jawe populace.

Capt. Muljono brought us down from the Iwan. We had learned how to use the girin (Garand) gun. I was puzzled when we were not led back to Long Nawang, but entered the Pengian and Penasai River. When we were ordered to haul the canoes up the ridge, we suddenly knew that we were about to attack Sarawak. After reaching Long Iran we were told that we were about to attack the Gurkha outpost at Long Jawe. I felt awkward since I stayed at Long Jawe on my way from Sibu less then four months before. Some younger men in our party were excited. They had never been in a war before. It was very hard to maintain our party's discipline and order. Only

39 Tom Harrisson, still heading the Batu Niah excavations and the Museum back then, was appointed senior intelligence advisor to the British army stationed in Sarawak (Miri). He thus had authority or influence to issue such clearance orders. See Heimann 1998.

$40 \quad$ Interview with Ubang Ding, Long Nawang, February 2003.

41 Sarawak Tribune 2 October 1963 and 8 October 1963. 
one day before reaching Long Jawe, some young men couldn't stand not shooting at some low flying birds. Others just thought it was another peselai expedition, like on that night before the raid, some even wanted to hunt for wild boar. The Captain, a Bugis, threatened to send those men back to Long Nawang.

I was sent ahead to inform the Long Jawe villagers about the impending attack, and to ensure that the right bank where the outpost was stationed would be cleared from our (Kenyah) people. I returned to our party who were already preparing to launch the attack. Everyone was hungry.

In the early morning hours we raided Long Jawe. I was ordered to shoot the radio tower. I wasn't sure what happened after that, it was total chaos. We managed to overrun the Gurkha post, and the first thing I did was to open the storage where their rations were stored. I couldn't believe seeing tins of biscuits. I began to open the tins and eating as much as I could, and I totally forgot about the fight. Someone had to pull me out from there.

We were forced to take, I think six captured Uma' Kulit (Kenyah) border scouts with us, since we were not sure whether they would not alarm the other Gurkhas downriver. Back at Long Iran, two were executed by our military commanders. We had to bury them near the riverbank. We were uneasy about this. Some of these border scouts were still related to some men in our team. We silently released two of them that night, and reported to the Captain that they ran away. (Ibau Ncau). ${ }^{42}$

The vulnerability of inland borders to such cross-border raids led to a complete ban on upriver travel. Other Kenyah peselai teams who were held up by Gurkha patrols along the Balui River were, however, not forced into deportation, but were allowed to stay in Kayan and Kenyah villages close to the Belaga area until right after the Konfrontasi ended in 1966. ${ }^{43}$ In addition, in 1964, the Kapit Resident permitted 56 Apokayan Kenyah to continue to work on the Kapit airfield. Later they were joined by "no less than two hundred in all". ${ }^{44}$ In the Baram area, other groups were allowed to continue work under the protection of Temenggong Oyong Lawai Jau. ${ }^{45}$ Being held-up for prolonged periods, a number of peselai team members fell in love with local women, married, and naturalized, while others decided to invite their remaining families in the Apokayan to come over and settle in Sarawak.

In other cases, peselai teams that were held-up by the travel ban began to open rice farms in the Balui, which precipitated later permanent migrations into Sarawak. One Badeng Kenyah peselai team from Long Betaoh was held up

42 Interview with Ibau Ncau, Long Nawang, November 2006. See also Sarawak Tribune 2 October 1963 and 6 November 1963.

43 Interview with Dato' Tajang Laing, Kuching (March 2003), who was a member of the Council Negeri during the Konfrontasi period.

$44 \quad$ See Kapit District Annual Report Part II (July 1964) by Peter Tinggom (Sarawak Gazette 31 August 1965: 253). It was the first occasion when Kenyah labour migrants were reported under the 'Immigration' issue header.

45 Temenggong Oyong Lawai Jau, M.B.E., a Kenyah, was the Paramount Chief of the Sarawak Orang Ulu, and Sarawak Council Negeri member. He had close relationship with Kenyah leaders in the Apokayan due to his Leppo' Tau ancestry. Interview with PeLawai Asa, Nawang Baru (February 2003), who was working in the Baram during the Konfrontasi. 
in the Balui, and decided to open rice fields close to Long Iran while waiting for the travel ban to be lifted. In 1966, shortly after the Konfrontasi ended, they decided that basic needs were more accessible in Sarawak, and they invited their relatives in Indonesia to settle there. The Long Iran settlement soon grew (it was even reported in Sarawak's 1968 health census - see Leigh [2002]), and later became the nucleus of the Badeng Kenyah settlement at Long Busang in 1969.46

The Konfrontasi, and the 1963 Long Jawe raid in particular, left what many thought was a deep scar to community relations in the Rajang river basin as community leaders, particularly in Sarawak, felt that it was a serious breach to the sacred 1924 Kapit Peacemaking Agreement. Despite the official signing of peace and the normalisation of diplomatic ties between Indonesia and Malaysia in August 1966, high-level Sarawak politicians from both the Rajang and Balui thought that a separate transnational peacemaking agreement following the 1924 Kapit tradition should be arranged. Tajang Laing, a Balui Kayan and then Sarawak Forestry Minister, traveled up to Long Nawang in mid-1967 to make the necessary arrangements. The peacemaking agreement was to involve all the Iban, Kayan and Kenyah communities of the Rejang, Balui, and Kayan rivers following the 1924 Kapit peacemaking ceremony ${ }^{47}$

We wanted to arrange peace following our Kayan-Kenyah traditions. After all, we all originated from Indon. My own Kayan ancestors came from the Apokayan. I was maybe the only Sarawak official who personally knew many people from Long Nawang. That's why I was sent out by (Temenggong) Jugah to go on a peacemaking mission to Long Nawang. So I went, but coming closer to the border, we were not too sure about how we would be received in Long Nawang. We went up the Iran River and waited just at the border. We luckily met two Kenyah from Long Nawang, and we asked them to summon the leaders of the Apokayan to meet us on the border. I told them that we all have breached our forefathers' peace agreement, and that we should arrange the peacemaking at Long Jawe. I was relieved when they accepted. (Tajang Laing, 2003). ${ }^{48}$

Meanwhile, Temenggong Jugah, who was then the Federal Minister for Sarawak Affairs, secured 10,000 Malaysian Dollars from the Malaysian Prime Minister, Tunku Abdul Rahman, to fund the ceremony. The peacemaking ceremony itself was considered anti-climactic by Temenggong Jugah, who apparently missed the spearing of pigs which was a tradition under Brooke rule. One reason why the old custom could not be followed was that the majority of the Apokayan Kenyah had already become Christian and shunned "pagan" rituals (Sutlive 1992). The Long Jawe peacemaking agreement was however not free from new statist considerations, as Sutlive (1992: 215-216) wrote:

46 Interview with PeAsan Lusat, Long Busang, Feb. 2003. PeAsan was a member of this initial peselai team held up in the Balui.

$47 \quad$ Interview with Dato' Tajang Laing, Kuching, March 2003.

48 Interview with Dato' Tajang Laing, Kuching, March 2003. 
He (Temenggong Jugah) then consulted with Gerunsin Lembat, at that time the State Secretary, about procedures for a ceremony. Both men recognized that as soon as such a ceremony was held, there would be a large movement of people from Kalimantan into Sarawak where economic conditions were better, creating a problem of refugees. Gerunsin discouraged Jugah from holding such a ceremony, but Jugah was adament.

Despite Gerunsin's objections, the way trans-basin relations overruled statist considerations came to the test when, in 1969, soon after the peacemaking was completed, thirteen Badeng Kenyah longhouses migrated from Long Betaoh in the Apokayan into the Balui:

As Jugah and Gerunsin had anticipated, one of the results of the ceremony was the mass migration of more than 2,000 of these Kenyah into Sarawak. The two men worked with appropriate government departments in the resettlement and the registration of these new citizens. (Sutlive 1992: 218).

\section{THE TIMBER BOOM: BECOMING ILLEGAL (BUT LICIT) ALIENS}

Following the end of the Konfrontasi, massive peselai expeditions commenced, but this time they raised concerns with Indonesian government officials. Fearing that peselai expeditions would become the pretexts for permanent migrations into Sarawak, coupled with significant shortages of labour in the Apokayan caused by the absence of a large number of men during prolonged peselai episodes between 1968-1969, the Government in 1970 limited the number of peselai participants allowed move on a single Pass Djalan to a maximum of 20 persons. ${ }^{49}$ There was a brief diversion of peselai activities in the early 1970s to banjir kap logging activities in East Kalimantan's lower Kayan area. These small-scale logging activities ended as soon as the Indonesian Army's Special Forces (RPKAD) took over the banjir kap business. ${ }^{50}$

Sarawak's increased timber industry expansion since 1974, prompted by the Federal takeover of Sarawak's state oil revenues, attracted a new influx of Indonesian labour, including an increased influx of peselai groups. These groups also included members who originated from Kenyah settlements that had migrated out of the Apokayan. ${ }^{51}$ New logging technologies, such as the utilization of tractors (lipan) and chainsaws, changed the processes of labour recruitment significantly. No longer in need of the mass labour that the $k u d a-$ kuda (manual hauling) system required, logging camp recruiters broke up peselai teams into smaller units once they arrived in major logging towns.

49 See Whittier (1973: 133-134).

50 Interview with Tamen Baun, Long Nawang, May 2000. Banjir kap logging was a smallholder timber extraction activity whereby upriver communities sold logs to downstream timber purchasers - this is carried out by marking their logs and letting them float downstream during high water levels. After a period they would come down to collect payments, calculated on log quantities marked by each feller. After a short while, the RPKAD (Resimen Para Komando Angkatan Darat - since 1985 renamed to KOPASSUS / Komando Pasukan Khusus) took over the role as log purchasers. The RPKAD was widely accused for cheating by erasing log marks.

51 The political economy of Sarawak's timber industry has been exhaustively examined by Amarjit Kaur (1998a), Majid-Cook (1999), and Jomo et al. (2004). 
Single groups were often broken up and dispersed to different employers. Losing contact, it became increasingly difficult for smaller teams to hook up and organize the journey back home. It would be arduous for five persons, for example, to paddle and haul purchased goods through treacherous waterways back to the border. Similar to what happened during the Konfrontasi, many men ended up settling permanently in Sarawak, or in many cases, peselai durations often stretched beyond the one to three year periods. ${ }^{52}$

All during the mid-1970s, peselai teams began to experience the effects of the tightening of immigration controls, marked by the increase of police checks at major logging towns, such as Sibu, Bintulu, and Miri. It was during the 1980s when local Sarawakians, mainly Ibans, Kayans and local Kenyah, started to gradually pull out of hazardous positions in logging jobs (that is, chainsaw operators), which further compounded labour shortages in the logging industry ${ }^{53}$ Employers turned towards the eager surplus of Indonesian workers. While legal Indonesian Javanese, Malay, and Bugis workers filled the gaps in the downriver sawmill and plywood industries, vacancies in the more hazardous upriver logging jobs were filled by undocumented Torajans, Iban, Kenyah, and Kayan workers from Indonesia. Driven by profit, upriver logging camps preferred employing undocumented workers.

Nationwide Malaysian police raids on illegal migrants, starting with Nyah ('Get Rid Off') Operations in the mid-1980s, restricted Kenyah labour migrations from heavily patrolled urban areas. Nonetheless, many Indonesian Kenyah could pass off as local Sarawakians as police officers were usually unable to distinguish them from the local Kenyah populace. Some even cut their hair in traditional Kenyah fashion to blend in. ${ }^{54}$ In addition, significant proportions of the local Sarawak populace did not possess Identity Cards themselves. The ongoing citizen registration process in upriver areas was an opportunity for Indonesian Kenyah migrants to naturalize with the help of local Kenyah hosts acting as guarantors. Tajang Laing, a local Kayan politician with links to Kenyah leaders in the Apokayan, accordingly provided 200 Indonesian Bakung Kenyah plantation workers at Sepakau with Sarawak Identity cards around $1985 .{ }^{55}$ Following nationwide crackdowns on illegal immigrants, the role of Sarawak Kenyahs and politicians who had personal or kinship relations with peselai team members became more prominent in providing protective measures against police checks. This, however, placed many Apokayan Kenyah in asymmetrical power relations with their Sarawak kin through indebtedness.

52 Interview with Jakob Udau and Balan Laban at Uma Nyaving, Sungai Asap (March 2003); Garau Dian, Tasa Jok, PeLah Along and PeBit Ncau, Long Mekaba, December 2002.

53 Inadequate insurance and compensation rendered logging jobs more and more unattractive in the face of better jobs that Sarawakians could find in urban areas. See also Majid-Cooke (1999).

54 The traditional Kenyah hairstyle is marked by a long pigtail. This has gone out of fashion in Kalimantan since the 1960s, but was preserved among the Sarawak Kenyah until quite recently.

55 Interview with Dato' Tajang Laing, Kuching, March 2003. 
Two developments significantly altered the socio-economic relationship between the Apokayan Kenyah and Sarawak. First, the successive timber booms in Sarawak, which peaked in the 1970s and onwards marginalized the longstanding trade of jungle products into and out of Sarawak. Losing one of their primary economic niches, the Apokayan Kenyah's role in the Sarawak economy was relegated to supplying the pool of labour under the vast hierarchy of the timber industries. In addition to being relegated to the lower strata of the production hierarchy, the increased formalization of the Malaysian-Indonesian border in the 1980s categorised them as 'illegal migrants' without access to insurance and labour rights. It is no longer safe for Apokayan Kenyah to enter towns in Sarawak to cash in their wages at local banks without running the risk of being apprehended by increasingly frequent police checks in downriver regions. They often have to rely on camp canteen managers to cash the money for them, subject to a $5 \%$ commission.

Hitching on logging pickup cars is not always a convenient undertaking. Sarawak Iban drivers, higher in the ranks within the camp hierarchy, often refuse to take Apokayan Kenyah workers on their rides unless they pay a hefty fee of RM 50 (although camp regulations explicitly forbid any form of payments or bribes made for the utilizing of logging vehicles).

Their insecure status as illegal migrants has also affected the preferences of cross-border marriages. It was common up to the early 1980s for Apokayan man to marry Sarawakian women. By the 1990s, cross-border marriage rates in Central Borneo had gone down. Even among the small numbers of recent marriages, the trend has reversed in Sarawakian man marrying Indonesian women. ${ }^{56}$

Younger Apokayan generations who arrive in Sarawak today have scant geographic knowledge of village locations and rivers. Confined to logging camps, they have little contact with the outside world. Although the extensive logging roads have made travelling around Sarawak, especially to logging towns much easier, they no longer meander through the traditional cluster of Kenyah and Kayan villages that used to function as transit sites, social safety nets, and sites for socializing.

\section{FROM RIVERINE TO TERRESTRIAL SPACE ORDERING: THE NEW "BORDERS"}

The history of Kenyah mobility into Sarawak illustrates the changing nature of space ordering since the arrival of colonial states and the resulting impact it has had on cross-border social relations and the emergence of state border regimes. The early Sarawak state under the Brookes chose to insert itself

56 For example, in the village of Long Mekaba, a Kenyah settlement in the Baram, there was a time around 1978 when six Indonesian Kenyah man managed legally to marry women from the local populace. Only one cross-border marriage occurred in 2000 when a Sarawak Kenyah man married an Indonesian Kenyah woman, but because the bride did not have a birth certificate or a passport, the Sarawak authorities refused to legalize the marriage. (Interview with Ingkong Lahang and William Ukeng, Long Mekaba, January 2003.) 
within the indigenous riverine-based social order. It did so by improving social relations between riverine communities that extended from Sarawak's west coast up to the Apokayan in Dutch Borneo. Peace in the interior was viewed as a pre-requisite to a booming trade in forest products which was essential for the Sarawak economy. By basing itself on this riverine-based governance over space, the Brookes considered the Apokayan and its Kenyah inhabitants as an integral Sarawak social and economic space. This entailed that Sarawak had little interest in exercising control over the Anglo-Dutch international boundary, which paid little respect to the social-cultural and economic continuums that transcended the border. This longstanding riverine space order existed well into the transitionary period under British rule (19461963). The Kenyah of the Apokayan were not regarded as "Indonesians" or "aliens", even in the midst of the Konfrontasi.

Conditions started to change with the resurgence of Sarawak's logging industry, which spread inwards to the interior after the Konfrontasi had ended in the late 1960s. The logging industry, Sarawak's major revenue earner, is basically a terrestrial enterprise that partitions lands into neatly bounded concession areas. The accessibility to timber reserves requires the introduction of new modes of transportation and infrastructure such as trucks, pickups, and land roads. The extensive network of logging roads not only changed the physical landscape throughout Sarawak, but also increasingly shifted social organization away from the quasi-egalitarian order of river basins to the highly hierarchized world of logging camps.

It is within this hierarchized world of logging camps where the "border" is experienced. Far from being a territorial border, the border that separates Indonesians from Sarawakians is manifested through everyday life experiences: payments to Iban drivers, the small prospective of finding a Sarawakian spouse, wage differences, illegal deductions from salaries, and the limited access to their social world in general. The border is manifested through hierarchical power relations.

\section{CONCLUSIONS}

The traditional mobility patterns practiced by certain societies that may now be deemed "illicit" may be rooted in ancient trade routes that may have been the most efficient links between supply regions and regional markets. These very same routes are probably as efficient today as they were in the past, serving the same purpose under contemporary capitalist modes of development.

Capitalism requires an efficient order of hierarchical space that is relatively autonomous from the inefficiency of national space orders on one side, and natural barriers on the other. With the blurring between nation-state and corporate interests, the most effective border regime to support this would be a model that operates on hierarchical rather than territorial/spatial logic. This would entail the containment of people not through spatial partitions and borders, but through their containment within fixed hierarchies of capitalist production. The Kenyah have been subjected to new regimes of class 
relations, embedded in the encounter of structured labour hierarchies and in the emerging inscription of national identity within their social space, which has increasingly been reduced to a workplace. The two historical trajectories of the nation state and capitalism have found a working equilibrium in this encounter.

\section{REFERENCES}

Bauman, Z. 1998. Globalization; The human consequences. New York: Columbia University Press.

Beccari, O. 1904. Wanderings in the great forests of Borneo. Singapore: Oxford University Press. [1986 Reprint.]

Chew, D. 1990. Chinese pioneers on the Sarawak Frontier, 1841-1941. Oxford: Oxford University Press.

Eghenter, Cristina. 1999. "Migrants' practical reasonings; The social, political, and environmental determinants of long-distance migrations among the Kayan and Kenyah of interior Borneo", Sojourn, Journal of Social Issues in Sotheast Asia Vol. 14 No. 1 (April): 1-33.

Eghenter, Cristina. 2001. "Towards a casual history of a trade scenario in the interior of East Kalimantan, Indonesia, 1900-1999", in Bijdragen tot de Taal-, Landen Volkenkunde (BKI) 157/4: 739-769.

Elshout, J.M. 1923. Over de geneeskunde der Kěnja-Dajak in Centraal Borneo in verband met Hunnen Godsdienst. Amsterdam: Johannes Müller.

Harrisson, T. 1966. "A Kalimantan writing board and the Mamat Festival", Sarawak Museum Journal Vol. XIII No. 27 (Special Monograph No. 1; November): 287-295.

Heimann, J. 1998. The most offending soul alive; Tom Harrisson and his remarkable life. Honolulu: University of Hawai'i Press.

Ishikawa, Noburu. 2008. "Centering peripheries; Flows and interfaces in Southeast Asia", Kyoto Working Papers on Area Studies No. 10 (G-COE Series 8), December.

Ishikawa, M. and N. Ishikawa. 2005. "Commodifying Bornean forest; Transformation of the Kemena Basin society in Sarawak, Malaysia". Paper, the 22nd Annual Conference "Producing People and 'Nature' as Commodities in Southeast Asia", Center for Southeast Asian Studies, University of California, Berkeley, 4-5 February.

Jessup, T.C. 1981. "Why do Apo Kayan shifting cultivators move?", Borneo Research Bulletin Vol. 13 No. 1: 16-32.

Jomo K.S., Y.T. Chang, K.J. Khoo et al. 2004. Deforesting Malaysia; The political economy and social ecology of agricultural expansion and commercial logging. London: Zed.

Kaur, Amarjit. 1998a. Economic change in East Malaysia; Sabah and Sarawak since 1850. London: Macmillan.

Kaur, Amarjit. 1998b. "A history of forestry in Sarawak", Modern Asian Studies Vol. 32 No. 1 (February): 117-147. 
Langub, J. 1997. "Padan, Tusau, 1933-1996; A memorial”, Borneo Research Bulletin Vol. 28: 15-18.

Lefebvre, H. 1991. The production of space. Translated by D. Nicholson-Smith. Oxford: Blackwell. [Original book in French, 1973.]

Lumenta, D. 2008. The making of a transnational continuum; State partitions and mobility of the Apokayan Kenyah in Central Borneo, 1900-2007. PhD thesis, Graduate School of Asian and African Area Studies, Kyoto University.

Majid Cooke, F. 1999. The challenge of sustainable forests; Forest resource policy in Malaysia, 1970-1995. St. Leonards: Allen and Unwin.

Marx, K. 1973. Grundrisse; Foundations of the critique of political economy (rough draft). Translated by M. Nicolaus. London: Penguin.

Maxwell, A. R. 1999. "Balui reconnaissances; Notes on the oral history of the Belaga Malay community and early Belaga", Sarawak Museum Journal Vol. LIV No. 79 (December): 143-181.

Migdal, J., 2004. Boundaries and belonging: States and societies in the struggle to shape identities and local Practices. Cambridge: Cambridge University Press.

Nieuwenhuis, A.W. 1929. “Ten years of hygiene and ethnography in primitive Borneo", in: B. Schrieke (ed.), The effect of western influence on native civilisations in the Malay archipelago, pp. 10-33. Batavia: Kolff.

Ooi Keat Gin. 1997. Of free trade and native interests; The Brookes and the economic development of Sarawak, 1841-1941. Kuala Lumpur: Oxford University Press.

Pabit Enjok. 1965. "Five Leppo Tau Punishment Stories", Sarawak Museum Journal, Vol. XII No. 25-26 (New Series; July-December): 176-178.

Poelinggomang, E.L. 2002. Makassar abad XIX. Jakarta: Kepustakaan Populer Gramedia.

Prattis, I. 1963. "The Kayan-Kenyah Bungan Cult", Sarawak Museum Journal Vol. XI No: 21-22 (New Series, July - December): 64-87.

Pringle, R. 1970. Rajahs and rebels; The Ibans of Sarawak under Brooke Rule 18411941. Ithaca: Cornell University Press.

Reece, R.H.W. 1982. The Name of Brooke; The end of White Rajah rule in Sarawak. Kuala Lumpur: Oxford University Press.

Rousseau, J. 1990. Central Borneo. Oxford: Oxford University Press.

Schendel, W. van. 2005. "Spaces of engagement; How borderlands, illicit flows and territorial states interlock", in: W. van Schendel and Itty Abraham (eds), Illicit flows and criminal things; States, borders and the other side of globalization, pp. 38-68. Bloomington: Indiana Univerity Press.

Scott, J. 1998. Seeing like a state; How certain schemes to improve the human condition have failed. New Haven: Yale University Press.

Scott, J. 2009. The art of not being governed; An anarchist history of upland Southeast Asia. New Haven: Yale University Press.

Sellato, B. 2001. Forest, resources and people in Bulungan; Elements for a history of settlement, trade, and social dynamics in Borneo, 1880-2000. Bogor: CIFOR.

Sidang Injil Borneo. 1988. Buku cenderamata Sidang Injil Borneo Sarawak. Miri: Sidang Injil Borneo. 
Smith, N. 1990. Uneven development; Nature, capital and the production of space. Second Edition. Oxford: Basil Blackwell. [First edition 1984.]

Smythies, B.E. 1955. “Dr. A.W. Nieuwenhuis, 'A Borneo Livingstone”, Sarawak Museum Journal 29: 493-509.

Sutlive, V.H. 1992, Tun Jugah of Sarawak; Colonialism and Iban response. Kuala Lumpur: Fajar Bakti.

Thongchai Winichakul. 1994. Siam mapped; A history of the geo-body of a nation. Honolulu: University of Hawai'i Press.

Walchren, E.W.F. van. 1907. “Eene reis naar de bovenstreken van Boeloengan (Midden Borneo)", Tijdschrift van het Koninklijk Nederlandsch Aardrijkskundig Genootschap (KNAG) Vol. 2/XXIV: 755-844.

Whittier, H.L. 1973. Social organization and symbols of social differentiation; An ethnographic study of the Kenyah Dayak of Kalimantan (Borneo). Ph.D. thesis, Michigan State University, East Lansing. 